\title{
Level of Satisfaction of Public Service in Takalar Regency, Indonesia
}

\author{
Syamsiah Badruddin ${ }^{1}$, Wisudawan Husain ${ }^{2}$ \\ Institut Ilmu Sosial dan Manajemen STIAMI, Jakarta, Indonesia \\ Universitas Indonesia Timur, Makassar, Indonesia
}

\begin{abstract}
This study discusses the quality of public service of government apparatus and general satisfaction with the civil service, in this case, is the manufacture of electronic identity card. The type of research used in this study is the kind of explanative research with quantitative approach. Techniques of collecting research data through questionnaires with the population are the people who make the electronic identity card in the government office civil registration. The number of samples in this study was 183 people. The results obtained from this research are for the quality of public service, and public satisfaction with the service of the apparatus is in the quite satisfied category. From these conditions show that the government apparatus in serving the community is still not motivated as a people servant. As a public service, the government apparatus in the salary of the general tax should feel like serving rather than being served.
\end{abstract}

Keywords: Public Service, Level of Satisfaction, Service Quality

\section{Introduction}

Confidence in the government reflects the feelings that exist in society. So that if high levels of trust show that the community is happy, comfortable, secure and ultimately will support government policy [1]. Communities will tend to trust the government if officials and agencies adopt policies that are judged by society as a system that stands in their favour. But if the response to public complaints is not fast and as expected, then the trust of the community will decline. The actions of officials, although not representative of their institutions, also significantly affect the level of trust [2][3][4][5]. It seen if the official concerned to carry out actions that are not favoured by the community or perform actions that make people feel uncomfortable. The crisis of confidence in the officials' resulted in the decline of trust in the institution where the jurist occupied his position.

There are still many people who are dissatisfied with public servants or government services today that impressed to make it involved in providing services to the community. Whereas the procedures and standards of service are clear enough, but they are considered only as a formality only [6] [7]. Along with that, the public demand for quality services continues to increase from time to time. These requests grew in line with the growing awareness that citizens have the right to be served and the obligations of local governments to provide services [8].

There is an imbalance between public confidence across the region observed among ordinary people to the information literate. This crisis of public trust occurred against the government, people in business, non-governmental organisations and media [9]. Several factors can cause a crisis of public faith in the government, namely, first, because the leader is considered dishonest and then the head is seen as not competent on the duties and obligations it carries. The second factor, people also assume that the leader is not to his vision which is not pro-people.

Public service is any service activities undertaken by public service providers as an effort to meet the needs of service recipients and implementers of legislation [10]. Thus, the implementation of services taken by the government should be able to address the needs of the community and also implement the legislation-the legislation - the invitation.

While the measure of the success of service providers determined by the level of satisfaction of the recipient of service achieved if the recipient of services to get the service as needed and expected [10]. That is why the need for facilities for the community which is a government goal for the welfare of society and as a tool of satisfaction for the community and also implement and apply the implementation of legislation.

Provision of public services should focus on meeting the needs of the community both in quality and quantity as an effort to provide community satisfaction [11]. Community satisfaction is a benchmark of the success of public services provided by public organisations [12]. Implementation of regional autonomy policy in Indonesia raises high expectation for society, especially in the case of improvement of public service.

The rapid technological advances require agencies to follow technological developments. The early development of Information Technology led to a new revolution in the form of a conventional work shift to the digital era [12]. This change has also changed the perspective of everyone in doing various activities one of them is on the activities of government agencies. For that, an organisation needs an information system that supports the needs of government agencies in creating efficiency and effectiveness of work and in improving services to the community.

In line with that, the government also strives to realise the state apparatus that serves the community primarily directed also at improving the quality, effectiveness, and efficiency of all government administrative arrangements including the increase of human resources [12]. So that the whole more

\section{Volume 6 Issue 9, September 2017}




\section{International Journal of Science and Research (IJSR) \\ ISSN (Online): 2319-7064}

Index Copernicus Value (2015): 78.96 | Impact Factor (2015): 6.391

able to carry out the task and the best development, especially in serving, nurture, and foster initiatives and the active role of the community in development and responsiveness to the interests and aspirations of the people.

Public demand for the quality of service government apparatus will be higher considering the public awareness of rights and obligations growing. Society requires fast, appropriate, fair, transparent, effective and efficient service [12]. Therefore, to improve the quality of public utilities, the improvement of apparatus performance is significant.

This is in line with the government's concept as stipulated by the government in the Decree of the State Minister of Administrative Reform No. 63 of 2003 on General Guidelines for the Implementation of Public Service such as service procedures, service requirements, service personnel capability, service speed, equity services, and certainty of duty schedule.

All this to promote the excellent service so that it is expected to improve the service system both technically and administratively that support the achievement of the implementation of excellent service. In this regard, the government's policy to improve the quality of public utilities should plan transparently.

The activities of development and administration carried out by the local authorities are very numerous. One of them, among others, is the service of the local government in state affairs namely the service in the registration of identity cards. The identification card service, in this case, the electronic identity card is one of the functions of government activities that aims to record all residents who live in the territory of an area and will eventually create a population order.

The importance of electronic identity card ownership for citizens is a proof of themselves and also at the same time provide data to the government about the state of the population who live in the territory of an area and will eventually create population orderliness. Enterprises to realise the needs of the community will be the ownership of identity cards for residents who are necessary identification documents, then the road taken is the provision of excellent service to the community.

\section{Method}

The type of research used is a quantitative approach that based on the purpose of investigation that intends to describe, explain and mean to interpret related problems.

The population in this study is the entire community who take care of the identity card in the Department of Population and Civil Registration Takalar District.

Determination of the sample in this study through the incidental sampling technique, i.e. taking samples from the community encountered at the time of taking care of the Identity Card in the Department of Population and Civil Registry Administration Takalar District, when viewed by the community faced it is suitable as a source of [13][14]. The number of samples in the study conducted was 183 people.

Data collection in this study using questionnaires is to provide a list of questions written and answered by the respondent himself that contains matters related to the quality of identity card service in the Office of Administration of Population and Civil Registration Takalar District. Where each question is available with 5 (five) alternative answers that strongly agree, agree, disagree, not align and firmly disagree. From the answer, the respondents just choose one alternative answer that considered by solid facts.

The education level of registered civil servants for master's degree (S2) as much as three people, one level (S1) as much as 1 and High School 9 people. Then from 13 employees are 6 of them are employee Sukuk and three employees honorary [15].

\section{Result and Discussion}

\subsection{Characteristics of Respondents}

Characteristics of respondents observed in this study include by gender, last education, age, and occupation of those interviewed. To know the details of the characteristics of respondents can see as follows:

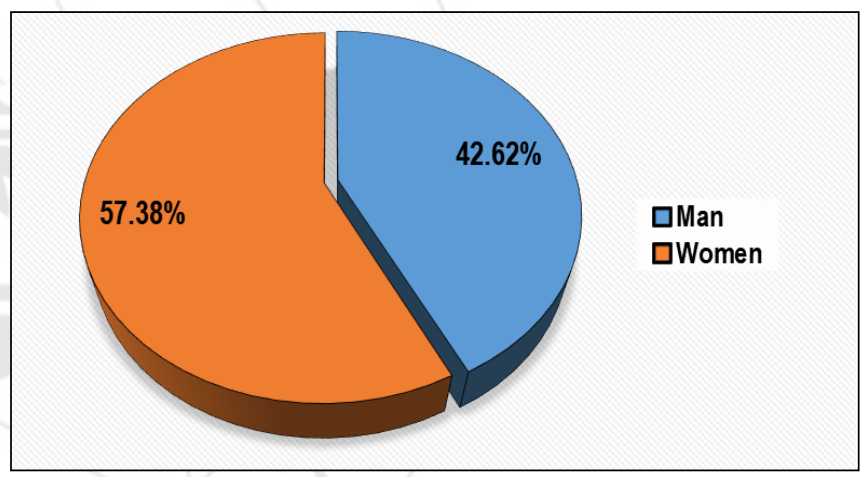

Figure 1: Distribution of Respondents' Sex

Figure 1 shows that of 183 respondent samples in this study, $57.38 \%$ or about 105 of them are female and $42.62 \%$ or about 78 of them male. From this result, it can conclude that the dominant gender genital in this research is a woman.

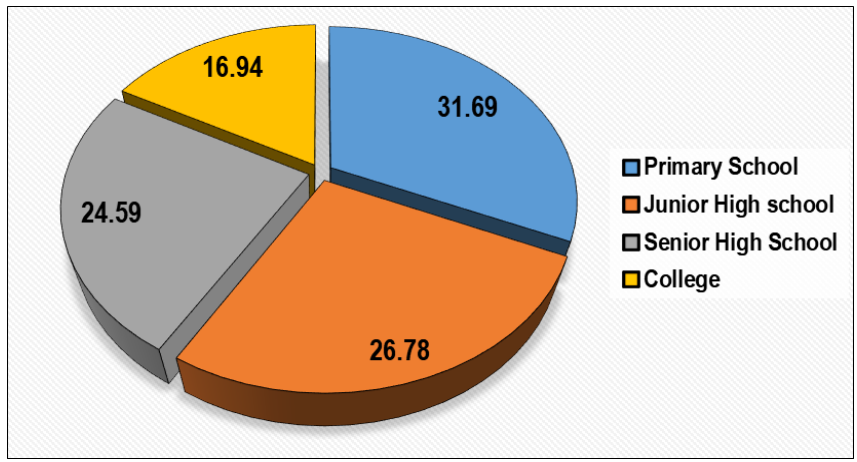

Figure 2: Distribution of Respondent Education Level

Figure 2 shows the final educational level of the respondents in this study totalling 183 . Primary school level of education with the percentage of $31.69 \%$ or 58 persons. Junior high 


\section{International Journal of Science and Research (IJSR) \\ ISSN (Online): 2319-7064}

Index Copernicus Value (2015): 78.96 Impact Factor (2015): 6.391

school instruction with a rate of $26.78 \%$ or 49 people. High school level of education with a rate of $24.59 \%$ or 45 people. Then the last one with college instruction obtained a rate of $16.94 \%$ or 31 people. From these results, it can conclude that the majority of teaching levels of respondents in this study is the junior high school level.

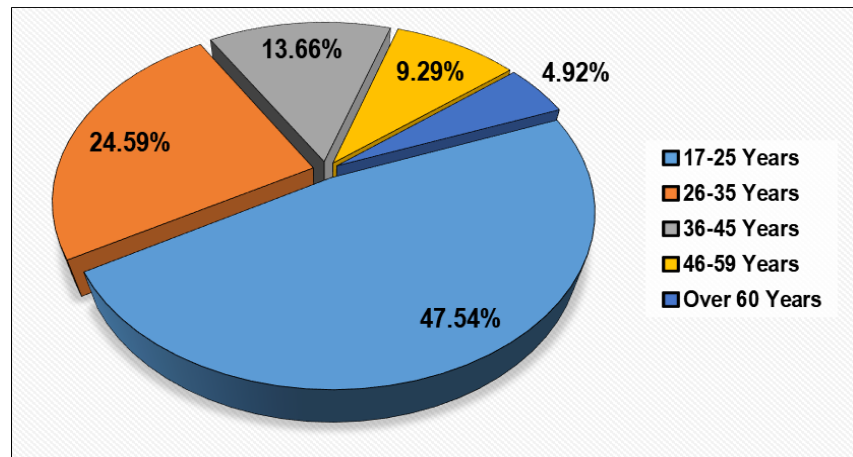

Figure 3: Distribution of Age Range of Respondents

Figure 3 shows the age distribution of respondents in this study. Minimum age took 17 years because at that age has been required to have an electronic identity card. Category of age between $17-25$ years obtained a percentage of $47.54 \%$ or about 87 respondents. Age groups between 26-35 years got a rate of $24.59 \%$ or 45 respondents. Category 36-45 years received a rate of $13.66 \%$ or about 25 respondents. Category of age between $46-59$ years got a rate of $9.29 \%$ or 9 respondents. Then the age group above 60 years got a rate of $4.92 \%$ or 9 respondents. From these results can be concluded that the age of those interviewed' dominant in this study ranged from 17-25 years.

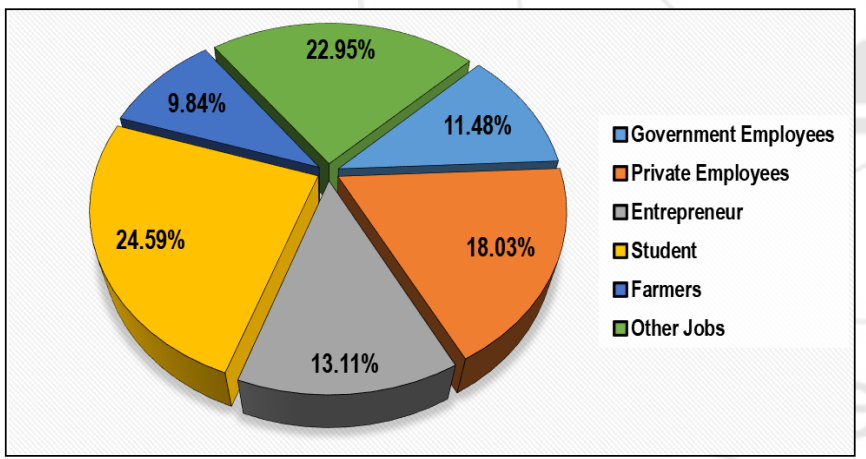

Figure 4: Distribution of Respondent Employment Type

Figure 4 shows the distribution of respondents' occupations in this study. For the kind of civil servant work obtained percentage $11.48 \%$ or about 21 respondents. Employment of private employees received a rate of $18.03 \%$ or about 33 respondents. Employment of self-employed earned rate $13.11 \%$ or about 24 respondents. Student work obtained $24.59 \%$ or about 45 respondents. The farmers' work received by $9.84 \%$ interest or about 18 respondents. Then other jobs (unskilled labourers, not working, fishers, contract workers) earned rate $22.95 \%$ or about 42 respondents. From these results show that the type of work or activity of the dominant respondents in this study are students.

\subsection{Service quality}

Quality of duty is an ability to adjust to the wishes or demands of the recipient (community) service with the services provided by the service providers by the conditions that have been determined [16]. From the research result obtained the quality of service as follows:

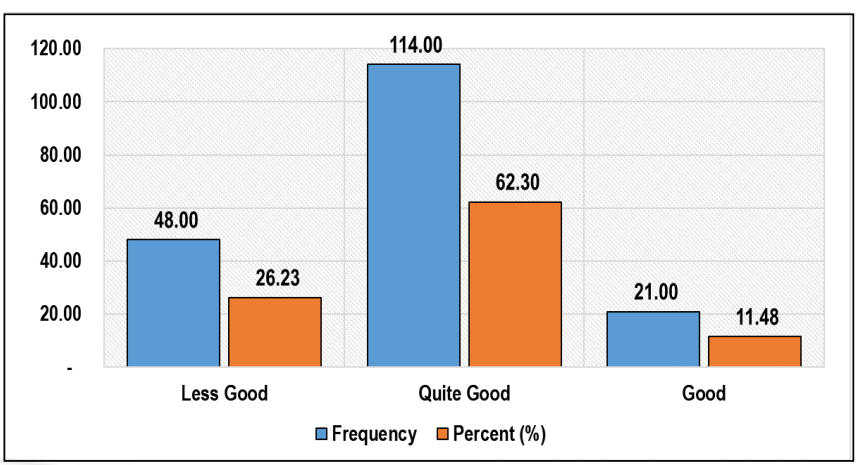

Figure 5: Public Service Quality Level

Figure 5 shows the standard of quality of public utilities perceived by the community. With 183 respondents obtained for the category of level of poor quality of public services amounted to $26.23 \%$ or about 48 respondents. Group of good quality of public service level of $62.30 \%$ or about 114 respondents. Then the last category is a good level of public service satisfaction of $11.48 \%$ or about 21 respondents. From these results can be concluded that the majority of the public still feel the quality of services provided by the government apparatus is good enough.

The still poor quality of public utilities in Indonesia also influenced by the lack of strong motivation from the appliance, state officials, or state apparatus to serve the community [17]. In carrying out its duties, the authorities appraised that the society should serve them, whereas the state apparatus should serve the community. By becoming a state apparatus, one tends to commercialise his duties to seek personal gain which will ultimately harm society [18].

In addressing the poor quality of public services, it is necessary to set standards for the delivery of public grievances with which the public can express their complaints [19]. Government agencies as public service providers can manage complaints from the public and improve the quality of their performance. Thus, public participation in public services will increase. Also, the government should make extensive coercion and harsh threats to all state apparatus to realise its duties and functions as public servants and not vice versa.

\subsection{General Satisfaction}

The level of feelings of pleasure or disappointment of a person after comparing the performance or outcomes he felt compared to expectations such as the comfort felt by the community at the time the service given, the belief of the community for the services provided, the feeling of satisfaction for the attention and service given by the service personnel [20]. From the results of research that has been 


\section{International Journal of Science and Research (IJSR) \\ ISSN (Online): 2319-7064}

Index Copernicus Value (2015): 78.96 | Impact Factor (2015): 6.391

done to obtain the results of community satisfaction as follows:

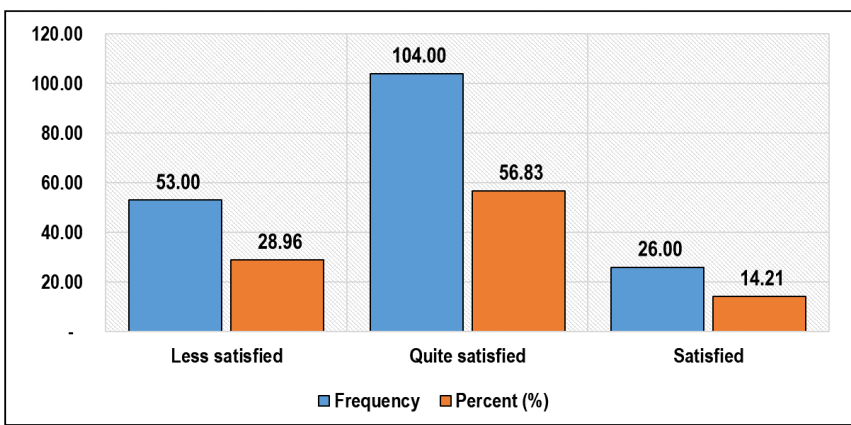

Figure 6: Public Service Satisfaction Level

Figure 6 illustrates the degree of public satisfaction with the service of the government apparatus, in this case, the process of making electronic identity cards. Of the 183 research samples, approximately 53 people or $28.96 \%$ of respondents answered less satisfied with the services provided by government officials. About 104 people or 56.83\% of respondents answered quite satisfied with the service of the staff. Then about 26 people or $14.21 \%$ of respondents answered satisfied with the services provided by government officials. From the results mentioned, we can conclude that the majority of people's satisfaction level of duty is in the category quite satisfied.

Public services in Indonesia still tinged with convoluted procedures, unclear costs, and many illegal charges that indicate that the quality of public services is still small. Also, there is a tendency of injustice in public services where poor people find it difficult to get services while people with money will get excellent service

Government agencies as providers of public services cannot perform their duties by the legislation that is as a public servant [21]. Government agencies that are supposed to assist the community in meeting their needs are detrimental to and complicate the community, especially the poor.

The following things can cause public service performance that has not been maximal in general:

- Little public oversight of public service delivery as a result of unclear procedures and standards of public services and lack of public complaints procedures for public utilities.

- The overlapping of duties and authorities of a government agency that causes the implementation of public services to be long and complicated, which tends to lead to abuse of power, corruption, collusion, nepotism, increasingly expensive fees, and discriminatory treatment of the community.

- Government agencies have not fully understood their duties and functions by the laws and regulations as the public servants.

The government should be customer-oriented: meeting customer needs, not bureaucracy. That is, the government must learn from the business sector where if not the focus and attention on the client (customer), then citizens will not be satisfied with the existing service or unhappy. Therefore, the government should place the people as clients who must be concerned with their needs. The government must begin to listen carefully to its clients, through customer surveys, focus groups and other methods.

The results of research in line with the theory put forward [22] explained that customer satisfaction would meet if the process of delivering services from service delivery to consumers by what perceived customers. Good service marketing system, the client must first understand about the existence of services offered.

Communities experience varying levels of satisfaction and dissatisfaction after experiencing or perceiving each service according to the extent to which their expectations are met or exceeded. Expectations are the internal standards that customers use to judge the quality of a service experience [23].

The tradition of bureaucratic officials during this time often apply rude and arrogant when serving citizens who come to his palace. This tradition must be changed by respecting them as sovereign citizens and should be treated well and reasonably. Among the advantages of customer-oriented systems is forcing service providers to be accountable to their customers, depolarizing decisions on the choice of service providers, stimulating more innovations, giving people the opportunity to choose between services, not wasteful because supply is tailored to demand, encouraging to become a committed customer, and create greater opportunities for justice.

\section{Conclusion}

Efforts to improve the quality of public services in Indonesia should outline in legislation that can form the basis for government agencies in implementing public services. The legislation also must be accompanied by sanctions that can force government agencies to perform their duties by minimum service standards.

Customer satisfaction (community) can achieve if the government apparatus directly involved in the service, can understand and appreciate and wish to perform excellent service. To be able to deliver excellent service, the device should know and understand the intent of the government apparatus as the public servant.

\section{References}

[1] G. Bouckaert and S. Van de Walle, "Government performance and trust in government," in Ponencia presentada en la Annual Conference of the European Group on Public Administration, Vaasa (Finlandia), 2001.

[2] G. D. Forster and S. K. Snyder, "Public attitudes towards government: Contradictions, ambivalence and the dilemmas of response," Rep. Recomm. Natl. Comm. Public Serv. Washingt. DC, pp. 19-42, 1989.

[3] L. B. Hill, The state of public bureaucracy. ME Sharpe, 1992.

\section{Volume 6 Issue 9, September 2017}

www.ijsr.net

Licensed Under Creative Commons Attribution CC BY 
[4] O. Listhaug and M. Wiberg, "Confidence in political and private institutions," Citizens and the State, vol. 1, pp. 298-322, 1995.

[5] H. G. Rainey, "Public opinion toward the civil service," Civ. Serv. Syst. Comp. Perspect., pp. 180-203, 1996.

[6] L. L. M. Bennett and S. E. Bennett, Living with Leviathan: Americans coming to terms with big government. University Press of Kansas, 1990.

[7] C. T. Goodsell, The case for bureaucracy: A public administration polemic. Sage, 2003.

[8] B. M. Huseby, "Attitudes towards the size of government," scope Gov., pp. 87-118, 1995.

[9] H. G. Frederickson, The spirit of public administration. Jossey-Bass Incorporated Pub, 1997.

[10]P. Frumkin and A. Andre-Clark, "When missions, markets, and politics collide: Values and strategy in the nonprofit human services," Nonprofit Volunt. Sect. Q., vol. 29, no. 1_suppl, pp. 141-163, 2000.

[11]R. C. Rich, "Voluntary Action and Public Services: An Introduction to the Special Issue." Sage Publications Sage CA: Thousand Oaks, CA, 1978.

[12] K. G. Provan and H. B. Milward, "Do Networks Really Work?: A Framework For Evaluating Public-Sector Organizational Networks.," in Academy of Management Proceedings, 1999, vol. 1999, no. 1, pp. A1-A6.

[13]R. K. Yin, Case Study Research Design and Methods (Applied Social Research Methods Series v. 5), 3rd ed. Thousand Oaks, California: SAGE Publications, Inc.

[14] K. S. Bordens and B. B. Abbott, Research Design and Methods: A Process Approach, 9th ed. New York: McGraw-Hill Education, 2014.

[15] Badan Pusat Statistik, "Provinsi Sulawesi Selatan Dalam Angka." Badan Pusat Statistik Kabupaten Takalar, Takalar, 2016.

[16]D. L. Goetsch and S. Davis, Quality management: Introduction to total quality management for production, processing, and services. Prentice Hall, 2006.

[17] J. L. Perry, "Measuring Public Service Motivation: An Assessment of Construct Reliability and Validity," $J$. Public Adm. Res. Theory, vol. 6, no. 1, pp. 5-22, 1996.

[18]K. Karunasena and H. Deng, "Critical factors for evaluating the public value of e-government in Sri Lanka," Gov. Inf. Q., vol. 29, no. 1, pp. 76-84, 2012.

[19]R. J. May, "The public interest standard: Is it too indeterminate to be constitutional," Fed. Comm. LJ, vol. 53, p. 427, 2000.

[20]R. Gerson, Measuring customer satisfaction. Crisp Learning, 1993.

[21] T. Christensen and P. Lægreid, "Trust in Government: The Relative Importance of Service Satisfaction, Political Factors, and Demography," Public Perform. Manag. Rev., vol. 28, no. 4, pp. 487-511, 2005.

[22]P. Kotler and G. Armstrong, Principles of marketing. Pearson education, 2010.

[23] C. H. Lovelock and L. Wright, Principles of service marketing and management. Prentice Hall, 2002.

Volume 6 Issue 9, September 2017 www.ijsr.net 